Dinamika Kesehatan Jurnal Kebidanan dan Keperawatan Vol 10 No. 1 Juli 2019 ( ISSN: 2086-3454 EISSN: 2549-4058)

url: http://ojs.dinamikakesehatan.unism.ac.id DOI : https://doi.org/10.33859/dksm.v10i1

Pengaruh Nafas Dalam Dan Mendengarkan Musik Gamelan Terhadap Tingkat Nyeri Pasien Post Operasi Fraktur Di RSUD Dr. Soediran Mangun Sumarso Wonogiri

\title{
Pengaruh Nafas Dalam Dan Mendengarkan Musik Gamelan Terhadap Tingkat Nyeri Pasien Post Operasi Fraktur Di RSUD Dr. Soediran Mangun Sumarso Wonogiri
}

\author{
Sumardi $^{1}$, Arlina Dewi ${ }^{2}$, Sri Sumaryani ${ }^{3}$ \\ ${ }^{1}$ Mahasiswa Magister Keperawatan Universitas Muhammadiyah Yogyakarta \\ ${ }^{2}$ Dosen Magister Manajemen Rumah Sakit Universitas Muhammadiyah Yogyakarta \\ ${ }^{3}$ Dosen Magister Keperawatan Universitas Muhammadiyah Yogyakarta \\ *Correspondence author : 08122595590, Email : mardasumardi@gmail.com
}

DOI: https://doi.org/10.33859/dksm.v10i1.390

\begin{abstract}
Abstrak
Latar Belakang: Indonesia menjadi peringkat ketiga Asia kematian korban kecelakaan lalu lintas. Penatalaksanaan patah tulang dilakukan dengan cara membatasi pergerakan tulang (imobilisasi) dapat dilakukan dengan cara Open Reduction Internal Fixation (ORIF). Managemen nyeri post operasi fraktur merupakan tindakan sangat penting dapat berupa nafas dalam dan mendengarkan musik gamelan.
\end{abstract}

Tujuan: Untuk menganalisis pengaruh nafas dalam dan mendengarkan music gamelan terhadap tingkat nyeri pasien post operasi fraktur

Metode: Penelitian dengan Jenis kuantitatif pendekatan quasi ekeperimen (pre-post test with control group design). Populasi penelitian ini adalah pasien post operasi ORIF (Open Reduksi Internal fixation) yang mengalami rawat inap dengan sampling menggunakan teknik simple random sampling sejumlah 30 responden. Kelompok intervensi diberikan nafas dalam dan mendengarkan musik gamelan, kelompok kontrol dengan nafas dalam dan mendengarkan musik instrumental.Penilitian dilaksanakan bulan Agustus - September 2018

Hasil: Uji statistik yang digunakan adalah uji $t$ - berpasangan yaitu paired $t$-test dan independent $t$ test. Penelitian menunjukkan bahwa niali $\mathrm{p}<$ value 0,05 sedangkan untuk nafas dalam dan mendengarkan musik gamelan serta nafas dalam dan mendengarkan musik instrumental dengan nilai $\mathrm{p}$ value 0,000 , Pada independent t-test nilai $\mathrm{p}=0,03$. Nilai $\mathrm{p}<0,05$ Sehingga nafas dalam dan mendengarkan musik gamelan berpengaruh terhadap perubahan tingkat nyeri secara bermakna pada pasien post operasi ORIF

Kesimpulan: Terdapat pengaruh nafas dalam dan mendengarkan musik gamelan terhadap perubahan tingkat nyeri pasien post operasi di RSUD dr. Soediran mangun Sumarso Wonohiri.

Kata kunci : Musik gamelan, nyeri 
Dinamika Kesehatan Jurnal Kebidanan dan Keperawatan Vol 10 No. 1 Juli 2019 ( ISSN: 2086-3454 EISSN: 2549-4058)

url: http://ojs.dinamikakesehatan.unism.ac.id DOI : https://doi.org/10.33859/dksm.v10i1

Pengaruh Nafas Dalam Dan Mendengarkan Musik Gamelan Terhadap Tingkat Nyeri Pasien Post Operasi Fraktur Di RSUD Dr. Soediran Mangun Sumarso Wonogiri

The effects of deep breathing and listening to gamelan music on the pain level of the patient after fracture surgery at RSUD Dr. Soediran Mangun Sumarso Wonogiri

\section{Abstract}

Background: Indonesia is ranked third in Asia, the death toll of traffic accident victims. Management of fractures is done by limiting bone movement (immobilization) can be done by means of Open Reduction Internal Fixation (ORIF). Postoperative fracture pain management is a very important action that can take the form of deep breathing and listening to gamelan music.

Objective: To analyze the effect of deep breath and listen to gamelan music on the pain level of post fracture surgery patients

Method: Research with quantitative type quasi-experimental approach (pre-post test with control group design). The population of this study was patients post ORIF (Open Reduction Internal Fixation) surgery who experienced hospitalization by sampling using a simple random sampling technique of 30 respondents. The intervention group was given deep breath and listened to gamelan music, the control group with deep breathing and listening to instrumental music. The study was held in August - September 2018

Results: The statistical tests used were paired t-test and independent t-test. Research shows that the value of $p<0.05$ value while for deep breath and listening to gamelan music and deep breath and listening to instrumental music with a p value of 0.000, In the independent t-test the value of $p=0.03$. Value $p<0.05$ so that deep breath and listening to gamelan music have a significant effect on changes in pain levels in patients post ORIF surgery

Conclusion: There is the influence of deep breath and listening to gamelan music on changes in the level of pain of postoperative patients in Dr. Soediran General Hospital Sumanguno Wonohiri.

Keywords: gamelan music, pain

\section{Pendahuluan}

Riset Kesehatan Dasar (2007), menjelaskan kasus patah tulang di Indonesia pada angka $4,5 \%$ pada tingkat seluruh dunia, Jawa Tengah sejumlah 4,7\%, kasus terbanyak pada rentang usia $>60$ tahun sejumlah 7,5\%. Patah tulang memerlukan tindakan perawatan yang serius untuk mencegah terjadinya hal yang tidak diinginkan (Kumagai, 2013).

Penatalaksanaan patah tulang dilakukan dengan cara membatasi pergerakan tulang (imobilisasi) dapat dilakukan dengan cara Open Reduction Internal Fixation (ORIF). ORIF merupakan tindakan operasi dengan menempatkan kembali tulang yang patah ke tempat semula dengan memasangkan plate dan bone screws ke dalam tubuh pasien dengan tujuan imobilisasi (Tanra,2007). Keluhan nyeri sering ditemukan pada pasien yang menjalani ORIF, bahkan kualitas nyeri setelah ORIF lebih tinggi. Menurut Sivrikaya (2012), operasi ORIF merupakan tindakan 
Dinamika Kesehatan Jurnal Kebidanan dan Keperawatan Vol 10 No. 1 Juli 2019 ( ISSN: 2086-3454 EISSN: 2549-4058)

url: http://ojs.dinamikakesehatan.unism.ac.id DOI : https://doi.org/10.33859/dksm.v10i1

Pengaruh Nafas Dalam Dan Mendengarkan Musik Gamelan Terhadap Tingkat Nyeri Pasien Post Operasi Fraktur Di RSUD Dr. Soediran Mangun Sumarso Wonogiri

pembedahan dengan tingkat nyeri paling berat..

Managemen nyeri post operasi fraktur merupakan tindakan sangat penting bagi dokter dan perawat, WHO (2015) telah merekomendasikan menggunakan analgesik untuk mengurangi nyeri. Pemberian obat analgesik dapat mengurangi nyeri karena analgesik dapat memblokade rasa sakit di perifer dan sistem syaraf pusat, walaupun demikian pemberian analgetik dapat mengiritasi lambung dan menyebabkan mual (Kumagai, 2013).

Pasien yang mendapatkan obat analgesik jenis Ketorolac 30 mg melalui intra vena menyampaikan masih merasakan nyeri berat (Novita, 2012). Terapi injeksi analgetik ketorolac $30 \mathrm{mg}$ hanya mampu menurunkan skala nyeri 1,5. Pasien post operasi fraktur setelah mendapat analgetik tetap merasakan nyeri dan skala nyeri semakin meningkat setelah 6 jam pasca pembedahan (Novita, 2012). Paracetamol injeksi $100 \mathrm{ml}$ khususnya di RSUD Dr. Soediran Mangun Soemarso sering digunakan, namun laporan dari pasien menyampaikan bahwa 1-4 jam awal nyeri berkurang namun pada jam berikutnya nyeri mulai muncul, hal ini disebabkan bahwa paracetamol injeksi mempunyai waktu paruh 1-4 jam saja (Yolanda, 2013).

Intervensi keperawatan yang dilakukan bertujuan untuk meningkatkan rasa nyaman yaitu nafasa dalam. Nafas dalam dapat mengatasi berbagai masalah misalnya stres, nyeri dan ketegangan otot (Perry \& Potter, 2006). Napas dalam dapat merangsang saraf otonom dengan mengeluarkan neurotransmiter endorphin yang akan meningkatkan kenyamanan dan menurunkan sensasi nyeri (Velkumary \& Madanmohan, 2004). Nafas dalam dan mendengarkan musik dapat menurunkan nyeri post operasi fraktur (Downey, 2009), dalam penelitian tersebut menunjukan bahwa nafas dalam mampu menurunkan nyeri. Penelitian serupa Syamsudin (2009), menyampaikan bahwa nafas dalam dapat mengurangi tingkat nyeri. Musik gamelan merupakan musik gending jawa yang sering dimainkan dalam acara pernikahan. Musik gamelan memiliki tempo 
Dinamika Kesehatan Jurnal Kebidanan dan Keperawatan Vol 10 No. 1 Juli 2019 ( ISSN: 2086-3454 EISSN: 2549-4058)

url: http://ojs.dinamikakesehatan.unism.ac.id DOI : https://doi.org/10.33859/dksm.v10i1

Pengaruh Nafas Dalam Dan Mendengarkan Musik Gamelan Terhadap Tingkat Nyeri Pasien Post Operasi Fraktur Di RSUD Dr. Soediran Mangun Sumarso Wonogiri

teratur, menenangkan, dan sederhana sehingga

orang yang mendengarkan musik gamelan

menjadi nyaman, tingkat nyeri berkurang dan

otot yang tegang menjadi rileks (Campbell, 2001).

\section{Bahan dan Metode}

Jenis penelitian menggunakan metode

kuantitatif dengan quasi ekeperiment, jenis rancangan pre-posttest with control group design yaitu rancangan yang menggambarkan hubungan sebab akibat. Kelompok intervensi diberikan perlakuan nafas dalam dan mendengarkan musik gamelan sedangkan kelompok kontrol diberikan intervensi nafas dalam dan mendengarkan musik instrumen. Populasi pada penelitian ini yaitu pasien rawat inap dengan diagnosa fraktur di RSUD Dr. Soediran Mangun Sumarso yang berjumlah \pm 30 pasien setiap bulannya. Teknik pengampilan sampel Probability dengan simple random sampling dengan jumlah sampel 30 responden. Penelitian dilaksanakan di RSUD Dr. Soediran Mangun Sumarso pada bulan Agustus-September 2018. Uji statistik yang digunakan adalah uji t-berpasangan yaitu paired t-test dan independent t-test karena berdasarkan uji normalitas data dengan Kolmogorov Smirnov diketahuai $\mathrm{p}>0,05$ sehingga data berdistribusi normal.

\section{Hasil Penelitian}

Analisis bivariat yang dilakukan dalam penelitian ini adalah untuk mengetahui pengaruh nafas dalam dan mendengarkan musik gamelan terhadap perubahan nyeri.

Tabel 1 Perubahan nyeri sebelum dan sesudah diberikan intervensi nafas dalam dan mendengarkan musik gamelan.

\begin{tabular}{|c|c|c|c|c|c|c|}
\hline $\begin{array}{l}\text { Respon } \\
\text { den }\end{array}$ & $\begin{array}{c}\text { variab } \\
\text { el }\end{array}$ & $\begin{array}{c}\text { Pre } \\
(\text { mean } \pm \text { SD })\end{array}$ & $\begin{array}{c}\text { Post } \\
(\text { mean } \pm \text { SD })\end{array}$ & $95 \% \mathrm{CI}$ & $\mathrm{t}$ & $\rho^{*}$ \\
\hline $\begin{array}{l}\text { Interven } \\
\text { si }\end{array}$ & VAS & $4.28 \pm 0.98$ & $3.74 \pm 1.19$ & $\begin{array}{l}0,31: \\
0,76\end{array}$ & 4,876 & 0,00 \\
\hline Kontrol & VAS & $3.03 \pm 0.93$ & $2.71 \pm 0.97$ & $\begin{array}{l}0,16: 0,4 \\
6\end{array}$ & 4,350 & 0,00 \\
\hline
\end{tabular}

Hasil uji paired-test pada kelompok perlakuan menunjukan bahwa setelah mendapatkan intervensi nafas dalam dan mendengarkan musik gamelan terjadi penurunan tingkat nyeri. Berdasarkan paired test terjadi penurunan tingkat nyeri dengan nilai t hitung hari pertama sebesar 4.876 dan hari kedua terjadi perubahan tingkat nyeri dengan nilai $\mathrm{t}$ hitung sebesar 4.350 . 
Dinamika Kesehatan Jurnal Kebidanan dan Keperawatan Vol 10 No. 1 Juli 2019 ( ISSN: 2086-3454 EISSN: 2549-4058)

url: http://ojs.dinamikakesehatan.unism.ac.id DOI : https://doi.org/10.33859/dksm.v10i1

Pengaruh Nafas Dalam Dan Mendengarkan Musik Gamelan Terhadap Tingkat Nyeri Pasien Post Operasi Fraktur Di RSUD Dr. Soediran Mangun Sumarso Wonogiri

berdasarkan analisa dari nilai t hitung tersebut diatas perubahan tingkat nyeri lebih terlihat di hari pertama pengkajian, yang berarti bahwa dengan intervensi nafas dalam dan mendengarkan musik gamelan nyeri pasien operasi lebih lebih efektif terjadi penurunan di hari pertama intervensi dibuktikan di tabel 1 dengan nilai probability pre test sebesar 0.200 dan post test sebesar 0.044 .

Management nyeri yang diberikan selama penelitian berlangsung mampu memberikan perubahan tingkat nyeri baik intervensi nafas dalam maupun dengan mendengarkan musik gamelan. Campell (2001), menyatakan bahwa mendengarkan musik dapat memberikan efek nyaman, otot yang tegang menjadi rileks, nyeri juga mengalami penurunan. Musik yang diberikan kepada responden dengan nada lembut dan rendah akan memberikan respon positif kepada pasien, sebagai contoh dalam penelitian ini, peneliti memilih musik gamelan karena sebagian besar responden penelitian dari daerah jawa sehingga responden sering terpapar musik tersebut sebelumnya dan musik gamelan juga memiliki tempo teratur, menenangkan dan sederhana, sehingga orang yang mendengarkan musik gamelan menjadi nyaman, tingkat nyeri berkurang dan otototot yang tegang menjadi rileks (Jokomono,2010) sehingga ketika terjadi nyeri baik karena fraktur maupun post operasi karena fraktur responden bisa mendistraksi dengan mengalihkan sensasi nyeri ke musik gamelan sehingga tingkat nyeri yang dirasakan berkurang.

Pada kelompok kontrol disajikan musik instrument oleh Kitaro dengan judul Koi durasi waktu selama 10 menit dengan bantuan headphone.Intervensi kelompok kontrol diberikan sama dengan kelompok intervensi yaitu dalam sehari diberikan tiga kali selama dua hari. Secara pengetahuan dan geografis responden mempunyai keterbatasan informasi tentang musik tersebut, bahkan mendengar musik instrumen tersebut mungkin juga baru pertama pada saat itu, namun karena musik yang dibawakan oleh Kitaro dengan judul Koi ini merupakan musik instrument yang lembut ternyata dapat mendistraksi responden 
Dinamika Kesehatan Jurnal Kebidanan dan Keperawatan Vol 10 No. 1 Juli 2019 ( ISSN: 2086-3454 EISSN: 2549-4058) url: http://ojs.dinamikakesehatan.unism.ac.id DOI : https://doi.org/10.33859/dksm.v10i1

Pengaruh Nafas Dalam Dan Mendengarkan Musik Gamelan Terhadap Tingkat Nyeri Pasien Post Operasi Fraktur Di RSUD Dr. Soediran Mangun Sumarso Wonogiri

penelitian dengan baik, terbukti secara statistik

bahwa kelompok kontrol juga dapat menurunkan nyeri secara signifikan dengan nilai t hitung 4.350 .

Stimulus yang menyenangkan pada musik instrument dapat melemaskan otot-otot, gangguan pikiran dari rasa sakit dan penyakit, membangkitkan respon yang efektif, dan melalui serabut saraf eferen menutup gerbang untuk persepsi komponen sensorik dan afektif nyeri (Good et al, 2005;. Baik \& Ahn, 2008), menurunkan ketegangan serta menstimulasi sistem saraf simpatis hipotalamus, yang mengaktifkan opiat endogen untuk menghambat transmisi impuls yang mengakibatkan rasa sakit. Persepsi penurunan nyeri melalui stimulasi mendengarkan musik secara umum adalah kemampuan otak untuk merangsang produksi endorfin otak, yaitu substansi alami yang membunuh rasa sakit (Prince, 1982; Scarantino, 1987; Crowe \& Barbara, 2004).

Mekanisme ini dikuatkan oleh penelitian Good et al. (2005) tentang pengaruh relaksasi dan musik pada nyeri setelah operasi usus.
Hasilnya dalam penelitian tersebut bahwa relaksasi, musik dan kombinasi keduanya efektif dalam mengurangi sensasi nyeri pasca operasi. Good\& Sukhe (2008) melakukan penelitian tentang efek music Korea dan musik Amerika untuk mengurangi rasa sakit setelah operasi ginekologi dan hasilnya adalah keduanya efektif untuk mengurangi rasa sakit. Mekanisme musik dalam mengurangi rasa sakit dapat dijelaskan oleh teori kontrol gerbang.

Kelompok kontrol dengan intervensi nafas dalam dan mendengarkan musik instrument Kitaro dengan judul Koi diberikan dengan durasi 10 menit setiap intervensi teryata dapat menurunkan tingkat nyeri. Hal ini sesuai dengan yang disampaikan oleh Perry\&Potter (2006) bahwa nafas dalammerupakan tindakan yang disadari untuk mengatur pernapasan secara dalam yang dapat menimbulkan efek relaksasi, menurunkan nyeri, ketegangan otot, hipertensi, gangguan pernapasan, dan lain-lain. Teknik relaksasi nafas dalam merupakan usaha yang dilakukan untuk menurunkan nyeri agar tidak terjadi 
Dinamika Kesehatan Jurnal Kebidanan dan Keperawatan Vol 10 No. 1 Juli 2019 ( ISSN: 2086-3454 EISSN: 2549-4058)

url: http://ojs.dinamikakesehatan.unism.ac.id DOI : https://doi.org/10.33859/dksm.v10i1

Pengaruh Nafas Dalam Dan Mendengarkan Musik Gamelan Terhadap Tingkat Nyeri Pasien Post Operasi Fraktur Di RSUD Dr. Soediran Mangun Sumarso Wonogiri

nyeri yang lebih berat dengan cara menurunkan ketegangan otot dan hal ini dapat meningkatkan sirkulasi lokal karena terjadinya vasodilatasi dalam pembuluh darah ( Priharjo, 2000).

Napas dalam dapat menstimulasi respons saraf otonom melalui pengeluaran neurotransmitter endorphin sehingga terjadi penurunan respons saraf simpatis dan peningkatkan respons parasimpatis (Potter\&Perry,2006). Stimulasi saraf simpatis meningkatkan aktivitas tubuh, sedangkan respons parasimpatis lebih banyak menurunkan ativitas tubuh atau nafas dalam dapat menurukan aktivitas metabolik lebihlebih dikuatkan dengan intervensi musik intrumental (Velkumary \& Madanmohan, 2004).

Tabel 2 Nilai selisih nyeri sebelum dan sesudah diberikan intervensi Nafas dalam dan mendengarkan musik gamelan

\begin{tabular}{llllll}
\hline $\begin{array}{l}\text { Nilai } \\
\text { selisih }\end{array}$ & Kelompok & Kelompok & Mean & $95 \%$ CI & \\
& $($ mean \pm SD) & $\begin{array}{l}\text { Kontrol } \\
(\text { mean } \pm \text { SD) }\end{array}$ & & & \\
difference & & $\rho^{*}$ \\
\hline VAS & $-0.36 \pm 0.38$ & $-0.25 \pm 0.40$ & -0.62 & -1.01 & 0,0 \\
& & & & & 3
\end{tabular}

* $\rho<0,05$ based on independent $t$-test

Pasien yang baru pertama menjalani operasi tentunya menjadi pengalaman baruyang menyakitkan karena merasakan adanya nyeri hebat yang ditimbulkan dari proses pembedahan dan patah tulang itu sendiri. Novita (2012), dalam penelitiannya menjelaskan pasien yang dilakukan tindakan pembedahan mendapatkan obat analgesik melalui intra vena masih merasakan nyeri hebat. Bahkan dari penelitiannya disampaikan terapi analgetik hanya dapat menurunkan nyeri pada skala 1,5. Didukung oleh penelitian Ekawati (2015), yang menyampaikan bahwa pasien yang menjalani proses pembedahan setelah mendapat analgetik intravena tetap merasakan nyeri dan skala nyeri semakin meningkat 6 jam setelah pembedahan.Penelitian ini responden dipilih sesuai kriteria inklusi salah satunya yaitu pasien yang mendapatkan terapi injeksi analgetik paracetamol $100 \mathrm{ml}$ intravena, peneliti menggunakan dasar penelitian novita (2015) yang menyampaikan bahwa pasien post operasi walaupun telah mendapatkan obat analgetik ternyata hanya dapat menurunkan nyeri 1-1,5 sehingga pasien perlu mendapatkan intervensi non farmakologi dari perawat. 
Dinamika Kesehatan Jurnal Kebidanan dan Keperawatan Vol 10 No. 1 Juli 2019 ( ISSN: 2086-3454 EISSN: 2549-4058) url: http://ojs.dinamikakesehatan.unism.ac.id DOI : https://doi.org/10.33859/dksm.v10i1

Pengaruh Nafas Dalam Dan Mendengarkan Musik Gamelan Terhadap Tingkat Nyeri Pasien Post Operasi Fraktur Di RSUD Dr. Soediran Mangun Sumarso Wonogiri

Paracetamol $100 \mathrm{ml}$ merupakan suatu analgesik jenis non-narkotik serta antiinflamasi yang menunjukkan aktivitas antipiretik yang lemah dan anti-inflamasi. Paracematol menghambat sintesis prostaglandin dan dapat dianggap sebagai analgesik dan antipiretik yang bekerja perifer karena tidak mempunyai efek terhadap reseptor opiat.

Penelitian ini responden mendapatkan intervensi nafas dalam dan mendengarkan musik gamelan (balabak, ladrang laras pelog pathet nem dengan 20-60 dB ) diberikan 4 jam setelah pemberikan injeksi paracetamol 100ml dengan harapan disaat diberikan intervensi pasien masih dalam rentang paro obat sehingga antara satu pasien dengan pasien lain dapat diberikan dalam rentang waktu yang sama. Paracetamol IV 100ml dapat diserap dengan cepat dan lengkap dengan waktu minimal pemberian selama 15 menit (tidak boleh lebih cepat). Bila dibandingakan dengan paracetamol serbuk, paracetamol IV atau acetaminophen lebih isotonik dengan $\mathrm{pH}$ 5,5 dan osmolaritas $290 \mathrm{mOsm} / \mathrm{L}$, sehingga larutan paracetamol lebih menyerupai osmolaritas plasma dengan $\mathrm{pH}$ yang tidak terlalu asam jika dibandingkan dengan propacetamol.

Penelitian disebutkan bahwa kejadian nyeri pada tempat injeksi secara bermakna lebih rendah pada kelompok paracetamol IV jika dibandingkan dengan kelompok propacetamol ( paracetamol serbuk dengan nilai $\mathrm{p}<0,001$ ) dengan cara pemberian yang sama. Moller (2005) menjelaskan bahwa pemberian paracetamol $100 \mathrm{ml}$ IV rerata 3 menit 45 detik adalah aman dan dilaporkan tidak terjadi eritema (kemerahan) pada tempat suntikan. Dalam penelitian tersebut tidak ditemukan efek samping selama proses pemberian obat analgetik dan 5 menit pasca pemberian obat IV (Jones, 2011) yang berarti bahwa selama penelitian tentang nafas dalam dan mendengarkan musik gamelan dalam penggunaan obat farmakologi tidak ada hal yang mengganggu selama pengambilan data seperti adanya kemerahan, alergi obat dan lain sebagainya.

Penatalaksanaanpasca operasi tidak 
Dinamika Kesehatan Jurnal Kebidanan dan Keperawatan Vol 10 No. 1 Juli 2019 ( ISSN: 2086-3454 EISSN: 2549-4058) url: http://ojs.dinamikakesehatan.unism.ac.id DOI : https://doi.org/10.33859/dksm.v10i1

Pengaruh Nafas Dalam Dan Mendengarkan Musik Gamelan Terhadap Tingkat Nyeri Pasien Post Operasi Fraktur Di RSUD Dr. Soediran Mangun Sumarso Wonogiri

hanya memberikan obat farmakoterapi, namun

bagaimana seorang perawat dapat

menciptakan rasa nyamanbagi pasien dalam waktu yang lama termasuk dalam penataksanaan ruang kamar tempat tidur pasien. Menurut Kolcaba (2005) banyak aspek yang harus dinilai untuk menciptakan rasa nyaman pasien salah satunya adalah faktor lingkungan. Banyak aspek yang merupakan lingkungan disekitar pasien yaitu keluarga serta perawat merupakan orang yang peduli dengan pasien yang diharapkan dapat menciptakan dan meningkatkan kenyamanan pasien.

\section{Pembahasan}

Berdasarkan penelitian yang telah dilakukan di bangsal rawat inap peneliti melakukan penelitian di kelas III RSUD dr Soediran Mangun Sumarso Wonogiri. Ruang tempat penelitian diberikan jarak antar kamar pasien $\pm 1 \mathrm{~m} 2$ berupa pembatas dari kain, terdapat jendela pada bagian depan dan dua buah pintu yang selalu terbuka sehingga privasi dan tingkat kenyamanan pasien dimungkinkan terganggu. Berdasarkan penelitian lampu penerangan setiap kamar tidak maksimal. Hal tersebut akan sangat mempengaruhi kenyamanan pasien sehingga pelayanan yang diberikan perawat sudah maksimal namun hal lingkungan apabila tidak dikelola dengan baik maka tujuan dari Kolcaba (2005) untuk memberikan kenyamanan kepada pasien juga tidak dapat dicapai. Selama penelitian juga ditemukan adanya gangguan dari lingkungan karena terlalu dekatnya jarak antara satu pasien dengan yang lain ditambah dengan ruangan yang panas sehingga hal ini dikuatirkan mempengaruhi hasil penelitian.

Berdasarkan intervensi yang telah dilakukan dengan mendengarkan musik gamelan merupakan salah satu intervensi yang dapat meningkatkan rasa nyaman pasien dan ini merupakan salah satu dari ketiga kategori dalam memberikan kenyamanan kepada pasien yaitu mempertahankan homeostasis dan mengontrol rasa sakit (Kolcaba, 2005)

Kolkaba (2005), menyampaikan pemenuhan kebutuhan kenyamanan dipengaruhi oleh empat hal yaitu fisik, psikospiritual, sosial dan lingkungan. 
Dinamika Kesehatan Jurnal Kebidanan dan Keperawatan Vol 10 No. 1 Juli 2019 ( ISSN: 2086-3454 EISSN: 2549-4058)

url: http://ojs.dinamikakesehatan.unism.ac.id DOI : https://doi.org/10.33859/dksm.v10i1

Pengaruh Nafas Dalam Dan Mendengarkan Musik Gamelan Terhadap Tingkat Nyeri Pasien Post Operasi Fraktur Di RSUD Dr. Soediran Mangun Sumarso Wonogiri

Pemenuhan kebutuhan fisik untuk

memberikan kenyamanan dipengaruhi oleh

nyeri yang ditimbulkan dari tindakan

pembedahan, managemen nyeri apabila tidak

dikelola dengan baik maka akan

mempengaruhi tingkat kenyamanan. Dalam

penelitian ini managemen nyeri dengan

diberikan nafas dalam dan mendengarkan

musik gamelan selama tiga kali dalam sehari

dan selama dua hari dengan jenis gamelan

balabak, ladrang laras pelog pathet nem

dengan 20-60 dB setelah pasien mendapatkan

obat analgetik paracetamol 100ml.Untuk

memberikan kenyamanan kepada pasien harus

didukung beberapa hal agar dapat memberikan

hasil yang maksimal.

Hasil uji paired-test pada kelompok perlakuan menunjukan bahwa setelah mendapatkan intervensi nafas dalam dan mendengarkan musik gamelan terjadi penurunan tingkat nyeri. Kelompok kontrol mendapat terapi nafas dalam dan mendengarkan musik instrumental juga mengalami penurunan tingkat nyeri.
Berdasarkan independent t-test pada

kedua kelompok mengalami penurunan yang signifikan namun signifikansi lebih terlihat pada kelompok intervensi dengan nilai $\mathrm{t}$ hitung sebesar 4.876 (nilai p sebesar 0,00) bila dibandingkan dengan kelompok kontrol dengan nilai t hitung sebesar 4.350 ( nilai $\mathrm{p}$ sebesar 0,00 ) dengan hasil tersebut responden mengalami penurunan tingkat nyeri. Mekanisme musik gamelan mempengaruhi transmisi impuls dan dapat mengurangi rasa sakit. Menurut teori kontrol gerbang, terapi musik dapat mengurangi rasa sakit dengan memodifikasi transmisi impuls berpotensi menyakitkan di sumsum tulang belakang. Musik memberikan masukan ke dalam sistem saraf pusat yang hadir untuk musik daripada rasa sakit (Baik \& Ahn, 2008). Intervensi nafas dalam dan mendengarkan musik gamelan dapat mempengaruhi tingkat nyeri ditunjukan dengan adanya penurunan tingkat nyeri. Intervensi nafas dalam dan mendengarkan musik gamelan lebih berpengaruh signifikan terhadap penurunan tingkat nyeri bila dibandingkan dengan kelompok kontrol. 


\section{UCAPAN TERIMA KASIH}

1. Dr.Setyarini,M.Kes selaku direktur RSUD dr.Soediran mangun Sumarso Wonogiri

2. Fitri Arofaiti,S.Kep,Ns,MAN.,PhD selaku ketua program studi magister keperawatan muhammadiyah Yogyakarta

\section{DAFTAR PUSTAKA}

Anwar, S.R. (2010). Sembuh Dengan AlQur'an. Jogjakarta: Sabil

Apfelbaum JL, Chen C, Mehta SS, Gan TJ. (2003). Postoperative pain experience: results from a national survey suggest postoperative pain continues to be undermanaged. AnesthAnalg, 97,534540.

Arikunto Suharsimi. (2010). Prosedur Penelitian : Suatu Pendekatan Praktis, edisi revisi 2010. Jakarta : Rineka Cipta

Alaika.(2015). Pengaruh Pemberian Terapi Musik Gendhing Subositi terhadap Respon Nyeri pada Bayi yang dilakukan Imunisasi di Sukoharjo. Universitas Muhammadiyah Surakarta

Barker \& Ellen. (2002). Neuroscience Nursing A, Spectrum of Care. Second Edition. St.Louis Missouri: Mosby-Year Book, Inc.

Black, J. M., \& Hawks, J. H.(2005).MedicalSurgical Nursing (7thed.). Philadelphia: Saunders Elsevier

Briggs \& Dean (1998). A qualitative Analysis Of The Nursing Documentation Of
Postoperative Pain Management. Journal of clinical nursing, 7, 155-163.

Büyu"kyilmaz \& Asxtı (2010). Postoperative Pain Characteristics in Turkish Orthopedic Patients. Pain Management Nursing, 11 (2), 76-84

Coll A.M. , Ameen J .R.M. \& Mead D. (2004). Postoperative pain assessment tools in day surgery: literature review. Journal of Advanced Nursing

46(2), 124-133 diakses 11 juni 2017.

Dawana, S. (2010). Sex Differences in Pain and Pain-Related Disability among Primary Care Patients with Chronic Musculoskeletal Pain. American Academy of Pain Medicine Pain, 11, 232-239

Downey, L.V. (2009). The Effects of Deep Breathing Training on Pain Management in The Emergency Department. Southern Medical Journal,(102), 688-692

Denise, M.L. (2007). Sympathetic Storning After Severe Traumatic Brain Injury.Critical Care Nurse Journal, 27 (1), 30-37.

Demir, Y. (2012). Non-pharmacological in Pain Management, Paint-Management Current Issues and Opinions, Dr. Gabor Racz (Ed.), ISBN: 978-953-307-813-7

Dolin et al.,(2002). Effectiveness of acute postoperative pain management: I. Evidence from published data. British Journal of Anaesthesia, 89 (3):

Ekawati, Kiki.(2015). Profil Nyeri Dan Perubahan Hemodinamik Pasca Bedah Perut Bawah Dengan Ketorolak $30 \mathrm{Mg}$ Intravena. Universitas Sam Ratulangi.Manado.

Faradisi, F.(2010). Differences Effectivenes Between Murotal Therapy With Music Clasik Therapy To Decline In The Level 
Of Anxious On Patients Pre Operation Fraktur Extremity[Bachelor Thesis in Adult Nursing].Surakarta: Muhammadiyah University of Surakarta. [in Bahasa Indonesia]

Gould et al.(2001) Visual Analog Scale (VAS), Information point. Blackwell Science Ltd, Journal of Clinical Nursing, 10, 697-706.

Grace, P.A.,\& Borley, N.R. (2012).At a Glance Ilmu Bedah Edisi Ketiga. Jakarta: Erlangga

Haefeli \& Elfering. (2006). Pain assessment, review. Eur Spin J, 15, 17-24.

Hidayah, Taufik Nur (2013). Pengaruh Pemberian Murottal Al-Qur'an Terhadap Tingkat Nyeri Pasien Post Operasi Fraktur Ekstremitas di Rumah Sakit Orthopedi Prof. Dr. R. Soeharso Surakarta. Universitas Muhammadiyah Surakarta.

Hjermstad et al, (2011). Studies Comparing Numerical Rating Scales, Vebal rating scales, and Visual analogue Scales for assessment of Pain Intensity in Adult; a systematic literature review. Journal of pain and symptom management, 41 (6), 1073-1094.

Jokomono (2011). Intervensi Musik Gamelan Untuk Mengurangi Nyeri Dan Kecemasan Pada Pasien Fase Akut Di Unit Gawat Darurat. RS. Mardi Rahayu Kudus

Keogh, E. (2008). Sex Differences in Pain.Reviews in Pain.DOI: $10.1177 / 204946370800200203$

Kolcaba, Katharine., DiMarco, Marguerite. (2005). Comfort theory and its application to pediatric nursing .

Kolcaba, Katharine. (2003). Comfort theory and practice: a vision for holistic health care and research. New York : Springer Publishing Company

Kumagai \& Dewit.(2013). Medical Surgical Nursing, Concept and Practice. 2nd ed. Missouri; Saunders, Elsevier.

Kwekkeboom, L. K., \& Gretarsdottir. (2005). Systematic Review of Relaxation Interventions for Pain. Journal of Nursing Scholarship. Third Quarter,269277

Lewis, S.L., Dirksen, S.R., Heitkemper, M.M., Buher, L., Camera, I.M. (2011). MedicalSurgical Nursing (Vol. 1 8thed.). Missouri: Mosby Elsevier

Lindberg, M. F., Grov, E. K., Gay, C. L., Rustøen, T., Granheim, T. I., Amlie, E., \& Lerdal, A. (2013). Pain characteristics and self-rated health after elective orthopaedic surgery - a cross-sectional survey. Journal of Clinical Nursing, 22(9-10), 1242-1253.

Liung, L. (2012). From ladder to platform: a new concept for pain management. Journal Of Primary Health Care, 4(3), 254-258.

Lukman. (2013). Pengaruh Teknik Relaksasi Nafas Dalam Terhadap Intensitas Nyeri pada Pasien Post-Operasi Sectio Caesaria di Kota gorontalo. Universitas Negeri Gorontalo

Marimo\&D'Arcy.(2013). Critical care, Trauma \& Emergency Pain Management. New York: Springer Publishing Copany.

Mellzack\& Wall. (1965). Pain Mechanism, a New Theory.Science New Series, 150, 971-979.

Moayedi \& Davis. (2013). Theories of Pain: From Specifity to Gate Control. Journal Neurophysiol, 109, 5-12.

Novita (2012). Pengaruh Musik Therapi 
Dinamika Kesehatan Jurnal Kebidanan dan Keperawatan Vol 10 No. 1 Juli 2019 ( ISSN: 2086-3454 EISSN: 2549-4058) url: http://ojs.dinamikakesehatan.unism.ac.id DOI : https://doi.org/10.33859/dksm.v10i1

Pengaruh Nafas Dalam Dan Mendengarkan Musik Gamelan Terhadap Tingkat Nyeri Pasien Post Operasi Fraktur Di RSUD Dr. Soediran Mangun Sumarso Wonogiri

Terhadap Nyeri Post Operasi Open Internal Reduction And Internal Fixation ( ORIF) di RSUD Dr H. Abdul Moeloek Provinsi Lampung. Universitas Indonesia

Notoatmodjo, S. 2010. Kesehatan Masyarakat Ilmu \& Seni. Jakarta: Rineka Cipta

Notoatmodjo, S. 2008. Metodologi penelitian Kesehatan (edisi revisi). Jakarta: Rineka Cipta

Nursalam. 2008. Konsep dan penerapan metodologi penelitian keperawatan. Jakarta

Priharjo. R 2000. Perawatan Nyeri : Pemenuhan Aktivitas Istirahat Pasien. Jakarta : EGC

Peterson, Sandra. J., Bredow, Timothy S/ 2004. Midle ranger theories application to nursing research. Philadelphia : Lippincott Williamas \& Wilkins

Perry\& Potter. (2010). Fundamental Keperawatan. Edisi ke VII. Salemba.

Potter \& Perry-Stockert-Hall,(2006). Basic Nursing. Canada:Mosby Elsevier.

Reyes, R.M., \& Wall, A. (2006). Deep breathing. htt:www.psychsan diego.org/downloads/DeeepBreathing.p df, diakses tanggal 2 oktober 2017

Rihiantoro, Tori. (2008). Pengaruh terapi musik terhadap status hemodinamika pada pasien koma di Ruang ICU Rumah Sakit Lampung. Jurnal Keperawatan Indonesia. Volume 12.hal 115-120. Jakarta

Riskedas. (2007). prefalension of hypertensi and determinant in Indonesia. medicine newspaper, 59 (12).
Setiawan. (2011). Dampak negatif pemakian headphone. https :// kampretzone. wordpress. com/2011/12/27/dampaknegatif-pemakaian-headphone/ diakses 17 Maret 2017.

Sivrikaya G. (2012). Multimodal Analgesia for Postoperative Pain, Pain Management. Retrieved on desember 7,2017,from www. intechopen. com/download/pdf/26138

Syamsudin, Asniah.(2009). Efektifitas Terapi Relaksasi Nafas Dalam Dengan Bermain Meniup Baling-Baling Untuk Menurunkan Nyeri Post Perawatan Luka Operasi Pada Anak Di Dua Rumah Sakit Di Banda Aceh. Jakarta. Universitas Indonesia.

Smeltzer, S.C, Bare, B.G.\& Hinkle, J. (2003). Brunner and Suddarth's Textbook of Medical-Surgical Nursing. PhilaDelphia: Lippincott Williams\& Wilkins.

Tarwoto (2011). Pengaruh Latihan Slow Deep Breathing Terhadap Intensitas Nyeri Kepala Akut pada Pasien Cidera Kepala Ringan. Universitas Indonesia.

Velkumary, G.K.P.S., \& Madanmohan. (2004). Effect of Short-term Practice of Breathing Exercise on Autonomic Function in Normal Human Volunteers. Indian Journal Respiration, (120), 115121

WHO.(2012).Postoperative care. Diakses 18 Oktober 2017 , from:www.who.int/surgery/./Postoperati vecare.pdf 